\title{
Splenic Trabecula
}

National Cancer Institute

\section{Source}

National Cancer Institute. Splenic Trabecula. NCI Thesaurus. Code C33607.

Dense connective tissue structures composed of collagen, elastic, reticular fibers, and smooth muscle cells. They are projections from the splenic capsule into the parenchyma. The arrangement of the fibers permits the spleen to expand passively and to serve as a small temporary reservoir for blood. The trabeculae which orig inate at the hilus contain and support trabecular arteries and veins which enter and leave the organ at the hilus. Trabeculae from other areas of the capsule do not contain vessels. Arteries branching out of the trabeculae are immediately surrounded by lymphocytes forming the white pulp. 